\title{
Sistem Informasi Monitoring dan Reporting Quality Control Proses Laminating Berbasis Web Framework Laravel
}

\author{
Arief Herdiansah $^{1^{*}}$, Rohmat Indra Borman ${ }^{2}$, Sonia Maylinda ${ }^{3}$ \\ ${ }^{1,3}$ Fakultas Teknik, Teknik Informatika, Universitas Muhammadiyah Tangerang, Kota Tangerang, Indonesia \\ ${ }^{2}$ Fakultas Teknik dan Ilmu Komputer, Sistem Informasi Akutansi, Universitas Teknokrat Indonesia, \\ Bandarlampung, Indonesia \\ Email: ${ }^{1 *}$ arief_herdiansah@umt.ac.id, ${ }^{2}$ rohmat_indra@teknorat.ac.id, ${ }^{3}$ soniamaylinda@gmail.com
}

\begin{abstract}
Abstrak - PT Victory Chingluh Indonesia merupakan perusahaan yang bergerak dibidang industri manufacture yang memproduksi sepatu olahraga merk global, karena itu hasil proses produksi yang berjalan di setiap proses produksi harus merupakan hasil yang sesuai dengan standard kualitas yang sudah ditetapkan Perusahaan. Penelitian ini merupakan penelitian terapan yang dilakukan di bagian Quality Control $(Q C)$ PT Victory Chingluh Indonesia khususnya monitoring dan reporting proses laminating. Saat ini proses cek kualitas hasil produksi dan proses pembuatan laporan QC belum menggunakan sebuah sistem informasi berbasis komputer, hal ini membuat waktu yang diperlukan untuk laporan cukup lama dan laporan yang dihasilkan terkadang datanya tidak konsisten. Beerdasarkan hel tersebut peneliti merasa perlu untuk membantu mengembangkan sistem informasi monitoring dan reporting quality control. Dalam proses pengumpulan data, peneliti melakukan metode survey dan wawancana kepada staf terkait dibagian QC proses laminating. Peneliti menggunakan UML (Unified Modeling Language) dalam proses perancangan sistem informasi dan peneliti menggunakan bahasa pemrograman PHP dengan framework laravel dalam tahap pengembangan sistem. berbasis database dan web. Pada tahapan akhir pengembangan, sistem yang dihasilkan diuji dengan menggunakan metode pengujian black box. Sistem yang dihasilkan telah dapat membantu staf QC me-monitoring hasil pekerjaan QC dan membuat laporan QC hasil proses produksi dengan cepat dan tepat, sistem yang dihasilkan juga menghasilkan sebuah laporan dalam bentuk dashboard (grafik) yang dapat mempermudah manajemen untuk melakukan analisa laporan hasil produksi QC di PT Victory Chingluh Indonesia.
\end{abstract}

Kata Kunci: Laporan, Quality Control, Dashboard, Framework Laravel

Abstract - PT Victory Chingluh Indonesia is an industrial manufacturing company that produces global brand sports shoes, therefore the results of the production process in each production process must conform to the quality standards set by the Company. This research is an applied research conducted in the Quality Control (QC) Department of PT Victory Chingluh Indonesia, especially the monitoring and reporting process of the laminating process. Currently, the process of checking the quality of production results and the process of making QC reports have not used a computer-based information system, this makes the time required for reports quite long and the resulting reports sometimes have inconsistent data. Based on this, the researcher feels the need to help develop an information system for monitoring and reporting quality control. In the data collection process, the researcher conducted a survey method and interviewed the PIC in the QC section of the laminating process. Researchers use UML (Unified Modeling Language) in the process of designing information systems and researchers use the PHP programming language with a laravel framework in the system development stage. database and web based. At the final stage of development, the resulting system is tested using the black box testing method. The resulting system can help $Q C$ staff monitor the results of $Q C$ work and create QC reports on the results of the production process quickly and precisely, the resulting system has also produced a report in the form of a dashboard (graph) which can make it easier for management to analyze QC production reports in PT Victory Chingluh Indonesia.

Keywords: Report, Quality Control, Dashboard, Laravel Framework

\section{PENDAHULUAN}

PT Victory Chingluh Indonesia merupakan perusahaan industri manufacture yang membuat sepatu olahraga merk internasional untuk pasar eksport, saat ini Perusahaan memiliki karyawan lebih 15.000 karyawan. PT Victory Chingluh Indonesia memiliki konsep sebagai pabrik yang memiliki konsep ramah lingkungan dengan kualitas tenaga kerja yang terlatih dalam memproduksi sepatu olahraga yang berkualitas tinggi untuk kenyamanan para pelanggan atau pengguna.

Untuk dapat menghasilkan hasil produksi sepatu dengan kualitias baik yang dapat diterima pasar internasional, dalam proses produksi perlu dilakukan pemantauan yang ketat agar dapat dipastikan dihasilkan sebuah hasil akhir yang memenuhi standar kualitas yang diterapkan oleh perusahaan. Ketika Perusahaan menemukan cacat pada hasil produksi, Perusahaan akan cepat melakukan evaluasi hal-hal yang menjadi penyebab dan kendala dalam proses produksi, sehingga Perusahaan dapat dengan cepat melakukan perbaikan sehingga dengan cepat dapat diperoleh hasil produksi yang berkualitas. PT Victory Chingluh Indonesia juga memiliki prosedur kerja detail dan tenaga kerja bagian QC(Quality Control) terlatih dalam rangka menjaga kualitis barang yang dihasilkan. Kualitas merupakan keseluruhan sifat sebuah produk/jasa pelayanan yang dihasilkan Perusahaan dimana memiliki pengaruh dan kemampuan untuk memuaskan kebutuhan pengguna yang dapat dinyatakan atau tersirat [1]. Bagian QC merupakan bagian yang berperan penting dalam menjaga mutu 
produk yang dihasilkan sebuah perusahaan. "Pengendalian mutu hasil produksi merupakan hal penting yang wajib dilakukan oleh perusahaan industri (pabrik) untuk dapat menghasilkan produk yang sesuai dengan pesanan pelanggan" [2]. Metode pengerjaan dan pelaporan QC yang telah dioptimalkan akan menghasilkan proses QC yang lebih efektif mulai tahap awal(kickoff) penetapan bahan baku sampai akhir sehingga dapat mewujudkan deteksi dini jika terdapat adanya bahan yang kurang sesuai/abnormal [3].

Untuk dapat menjaga standarisasi kualitas produk yang dihasilkan diperlukan sistem informasi di bagian QC, yaitu sistem berbasis komputer yang merupakan sebuah himpunan dari berbagai komponen/elemen yang saling berhubungan dan teroganisasi berdasar fungsi-fungsi yang dimiliki sehingga menjadi satu kesatuan dan membentuk sebuah informasi. Pengertian informasi merupakan kumpulan data yang diolah menjadi sebuah informasi/pengertian kata yang berguna dan dapat dijadikan data masukan dalam proses pengambilan keputusan pimpinan karena informasi terbukti dapat menurunkan ketidakpastian dan meningkatkan pengetahuan [4] [5]. "Sistem informasi merupakan salah satu disiplin ilmu yang belum sepenuhnya mapan seperti matematikan dan ekonomi, sehingga sangat diperlukan pengetahuan dan pemahaman tentang ruang lingkup kajian bidang sistem informasi" [6]. Manajemen sebuah sistem informasi yang baik akan berhubungan erat dengan tata kelola data yang baik [7].

Berdasarkan hasil survey yang peneliti lakukan di bagian QC khususnya proses laminating dan berdasarkan hasil wawancara peneliti dengan PIC (Person in Charge) di bagian tersebut, didapat informasi dalam pengerjaan pembuatan laporan QC di proses laminating, saat ini staf bagian QC khususnya bagian laminating masih menggunakan cara konvensional, dimana staf QC akan menginput data hasil pengecekan proses QC laminating menggunakan aplikasi Microsoft excel untuk selanjutnya file tersebut diolah menjadi sebuah laporan yang diperlukan pimpinan bagian QC dan pimpinan bagian produksi untuk dijadikan data masukan dalam rangka membuat analisa dan perencanaan proses produksi selanjutnya. Dalam pelaksanaannya ternyata data yang dihasilkan bagian QC terkadang tidak sama atau terdapat perbedaan dengan bagian perencanaan (Planning) dan bagian produksi, hal ini dikarenakan masing-masing bagian melakukan pencatatan data dan membuat laporan masing-masing (dengan aplikasi Microsoft excel). Berdasarkan data dan informasi tersebut, peneliti memutuskan untuk membuat penelitian rancang bangun sistem dashboard monitoring dan reporting QC proses laminating pada PT Victory Chingluh Indonesia.

Selanjutnya peneliti melakukan analisa dan pertimbangan berkaitan dengan pemilihan bahasa pemrograman yang akan digunakan dalam proses pengembangan aplikasi dalam penelitian ini. Hal pertama yang peneliti pertimbangkan adalah keterbatasan sumber daya tenaga kerja di bagian QC yang tidak terlalu memiliki kemampuan IT (Information Technology) dalam hal pengelolaan dan pemeliharaan sebuah aplikasi dan database, selain itu peneliti juga mempertimbangkan belum tersedianya alokasi dana untuk melakukan investasi perangkat keras dan perangkat lunak yang besar untuk mendukung terimplementasinya sebuah sistem informasi yang ideal. Atas dasar hal tersebut peneliti memutuskan menggunakan database MySQL yang merupakan sebuah database tidak berbayar (gratis) dan peneliti memutuskan menggunakan bahasa pemrograman PHP yang sudah teruji dapat terkoneksi dengan baik dengan database MySQL. Untuk mempermudah, mempercepat dan menghasilkan tampilan aplikasi yang bagus dan mudah digunakan pengembangan aplikasi web yang open source, memiliki sintaks pemrograman yang ekspresif dan elegan serta penggunaan laravel yang merupakan salah satu framework PHP yang khusus dirancang untuk memudahkan dan mempercepat proses pengembangan aplikasi berbasis web. Untuk mempermudah pengguna melihat dan menganalisa laporan yang dihasilkan, maka sistem yang dikembangkan memiliki fitur laporan dalam bentuk dashboard (grafik). Dashboard merupakan salah satu alat bantu penting untuk menampilakn laporaan yang dapat digunakan memonitor keadaan sehari-hari atau hasil proses sebuah organisasi, dashboard juga dapat dijadikan alat penghubung tunggal untuk proses pengambilan keputusan [8] [9].

Beberapa penelitian terdahulu berkaitan dengan penelitian rancang bangun sistem informasi QC dan pengendalian kualitas antara lain: Penelitian yang dilakukan oleh Rahmayani dan Haryanto tentang "Rancang Bangun Aplikasi Monitoring Laporan Quality Control Dan Defective Produksi Sepatu Berbasis Web (Studi pada PT. Panarub Industry)". Penelitian ini adalah penelitian terapan dalam rangka mengembangkan aplikasi pengelolaan data hasil proses QC yang ada di Perusahaan agar dapat dijadikan sebuah sistem informasi yang dapat mengolah, mengendalikan dan memonitor data laporan QC dengan tujuan untuk peningkatan proses kontrol hasil produksi sepatu. Hasil dari penelitian yang dilakukan adalah sebuah sistem aplikasi berbasis web yang telah mudahkan manajemen mengelola dan memonitoring laporan QC [10]. Penelitian yang dilakukan oleh Berry Yuliandra, Ratri Fradinda Wulan tentang "Perancangan Sistem Informasi Pengendalian Kualitas pada Laboratorium Proses IV PT X “. Penelitian ini dilakukan pada salah satu industri semen di Indonesia berupa penelitian terapan merancang dan membangun sebuah sistem informasi pengendalian kualitas berbasis web (PHP) dengan tujuan meningkatkan proses monitoring dan kontrol pengendalian kualitas produk yang dihasilkan perusahaan dengan pemanfaatan aplikasi berbasis web. Penelitian ini telah menghasilkan sebuah sistem informasi berbasis web yang telah mampu membantu meningkatkan efisiensi dan meminimasi kelemahan sistem yang ada saat ini khususnya pada laboratorium proses IV yang dimiliki perusahaan [11]. Penelitian yang dilakukan oleh Fatmariani dan Alan Saputro tentang“Pemodelan Sistem Informasi Quality Control System (QCS) Sektor Industri 
Pariwisata Dinas Kebudayaan dan Pariwisata". penelitian ini merupakan penelitian pengembangan sistem informasi berbasis web menggunakan bahasa pemrograman PHP dalam rangka membuat sebuah pemodelan sistem informasi Quality Control System (QCS) pada sektor industri pariwisata dinas kebudayaan dan pariwisata provinsi Sumatera Selatan. Penelitian ini telah menghasilkan sebuah aplikasi yang membantu bagian umum dinas kebudayaan dan pariwista provinsi Sumatera Selatan dalam mendata semua potensi wisata yang dimiliki dan mengontrol serta memonitoring perkembangan, mendata jumlah pengunjung pusat-pusat pariwisata dan budaya provinsi Sumatera Selatan [12].

Perbedaan penelitian yang peneliti lakukan dibandingkan dengan penelitian sebelumnya terletak pada metode yang digunakan, objek penelitian, ruang lingkup penelitian, dan metode pengembangan sistem yang digunakan. Pada penelitian ini peneliti melakukan penelitian Quality Control (QC) dalam proses monitoring dan pembuatan laporan untuk mempercepat proses pembuatan laporan QC dan menjaga akurasi laporan kualitas barang yang dihasilkan oleh PT.Victory Chingluh Indonesia. Dalam proses pengembangan aplikasi peneliti tidak hanya menggunakan bahasa pemrograman PHP standard tetapi peneliti menggunakan framework laravel yang merupakan framework yang dapat membantu proses pengembangan aplikasi dan merupakan salah satu frameworks yang populer saat ini.

\section{METODE PENELITIAN}

\subsection{Tahapan Penelitian}

Peneliti menggunakan siklus Software Development Life Cycle (SDLC) model waterfall yang merupakan metode pendekatan pengembangan sistem informasi yang sistematis serta berurut mulai pada level komunikasi, perencanaan, pemodelan, konstruksi dan penyerahan sistem ke pengguna [13].

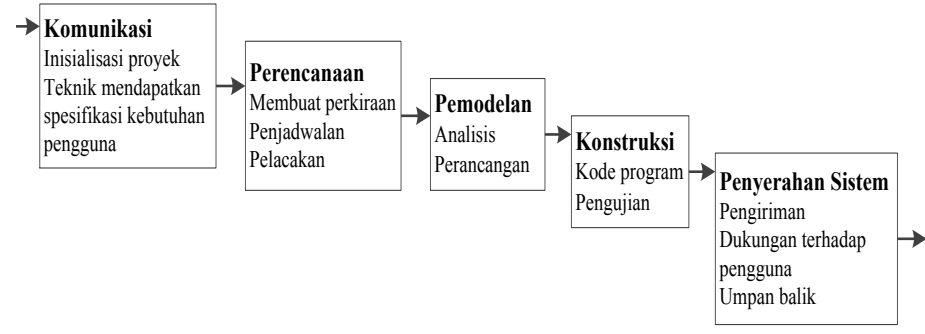

Gambar 1. Metode Waterfall [13]

Dalam proses rancang bangun sistem informasi monitoring dan reporting quality control berbasis web framework laravel, tahapan penelitian yang dijalankan sebagaimana gambar 2 .

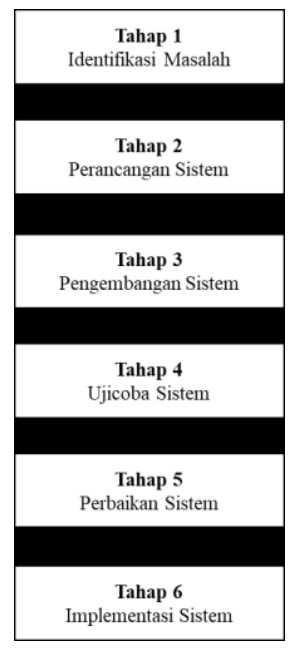

Gambar 2. Tahapan Penelitian

\subsection{Tahapan Identifikasi Masalah}

\section{Identifikasi masalah}

Tahap identifikasi masalah merupakan tahapan komunikasi antara peneliti dan narasumber penelitian yaitu staf bagian QC dan pimpinan bagian QC. Pada tahapan ini peneliti melakukan pengumpulan data dengan cara melakukan observasi langsung ke tempat penelitian, melakukan observasi dan melakukan ke bagian yang 
berhubungan dengan penelitian yang dilakukan. Beberapa indifikasi masalah yang penulis temukan ditempat penelitian antara lain:

1. Belum terkomputerisasinya proses pembuatan laporan QC sehingga proses pembuatan laporan QC kurang tepat, cepat dan akurat.

2. Laporan QC yang dihasilkan oleh PIC yang melakukan pencatatan dengan manual tingkat kesalahan datanya khusunya pemasukan kode material cukup tinggi, karena banyaknya referensi yang harus diperhatikan dalam membuat laporan tersebut.

3. Laporan hasil barang reject yang dibuat bagian QC terkadang tidak singkron dengan laporan bagian lain.

4. Laporan yang dibuat Qc terkadang sering hilang karena tidak terdokumentasi rapih dan tidak ada salinan.

5. Saat dibutuhkan laporan pada tanggal tertentu, sulit mencarinya karena belum terkomputerisasi, sehingga harus mencari dari tumpukkan laporan yang telah di buat.

\section{Identifikasi hak akses user}

Untuk menjaga keamanan data dan mencegah adanya pihak yang tidak berkepentingan mengakses sistem yang dikembangkan, peneliti membuat pengaturan hak akses pengguna (user permission) yang akan mengatur siapa saja pengguna yang berhak masuk ke sistem yang dikembangkan dan siapa saja yang dapat mengakses laporan yang dihasilkan.

\subsection{Tahapan Perancangan Sistem}

\section{Analisa sistem saat ini}

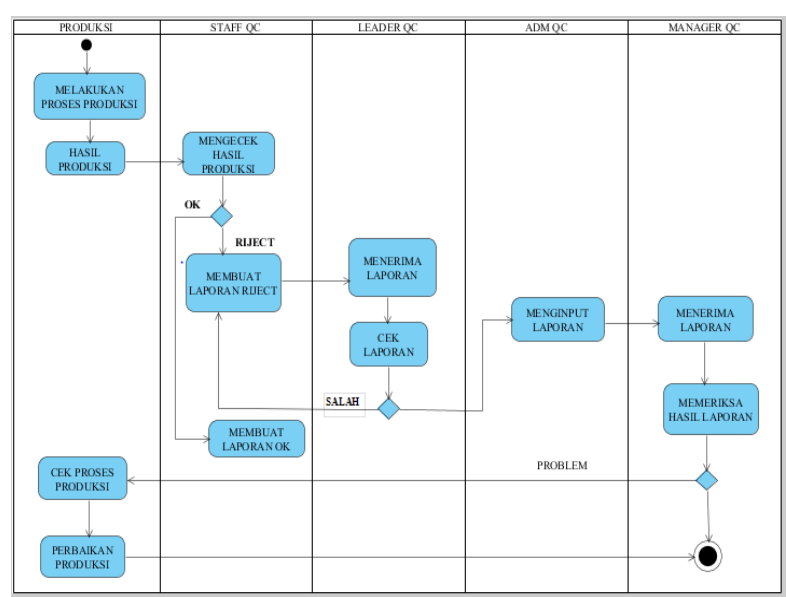

Gambar 3. Activity Diagram Alur Sistem yang Berjalan

Gambar 3 menunjukan sebuah diagram alur yang mengambarkan proses berjalan dimulai dari staf QC melakukan pengecekan kualitas terhadap matrial yang sedang dikerjakan, kemudian staf QC membuat laporan hasil temuan masalah yang ditemukan saat pengecekan. Selanjutnya staf QC membuat laporan (tulis tangan) dan menyerahkan laporan tersebut kepada pimpinan unit bagian QC untuk diserahkan ke admin/staf QC untuk dimasukan kedalam tabel aplikasi MS Excel. Admin/staf QC mencetak laporan hasil QC dan menyampaikan permasalahan yang terjadi di lapangan kepada manager bagian QC untuk ditindaklajuti. Jika terdapat permasalahan hasil produksi manager bagian QC akan melakukan kunjungan ke bagian produksi untuk melakukan pengecekan dan perbaikan terhadap penyebab permasalahn tersebut.

\section{Perancangan sistem usulan}

Peneliti menggunakan UML (Unified Modeling Language) dalam melakukan perancangan sistem yang dikembangkan. Peneliti melakukan perancangan dengan menggunadak use case diagram, activity diagram, sequence diagram dan class diagram. 


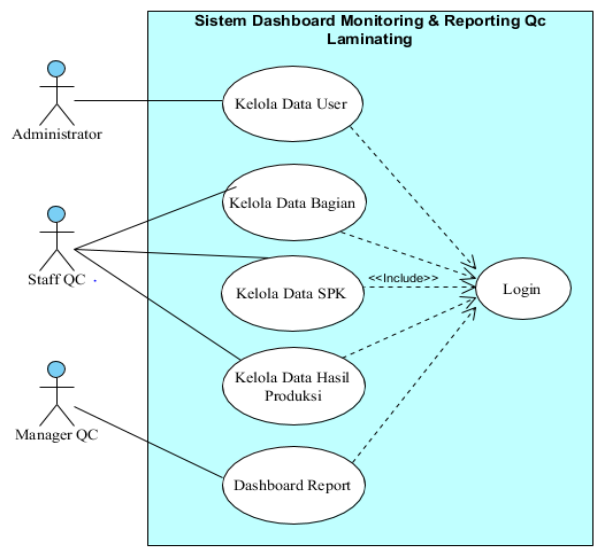

Gambar 4. Use Case Diagram

Gambar 4 merupakan use case diagram yang memberikan penggambaran hubungan setiap aktor (pengguna) dengan sistem yang dikembangkan. Sistem yang dikembangkan memiliki tiga aktor yaitu:

a. Administrator, merupakan pengguna yang memiliki hak akses sebagai administrator sistem, dimana mempunyai tugas mengatur hak akses pengguna dan melakukan pengaturan lain berkaitan dengan jalannya sistem.

b. Admin /Staf QC, merupakan pengguna yang memiliki akses melakukan pemasukan data QC dan membuat laporan yang dibutuhkan perusahaan.

c. Manager QC, merupakan pengguna yang dapat melihat semua laporan dan grafik yang dihasilkan sistem.

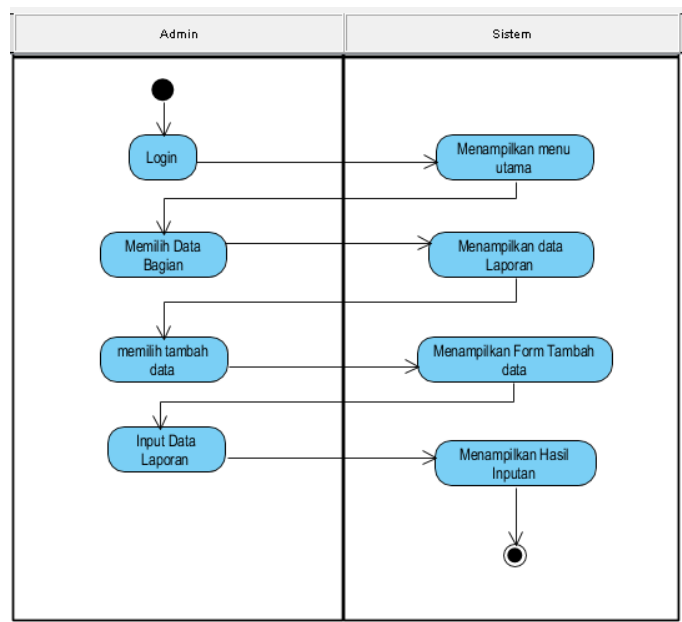

Gambar 5. Activity Diagram Kelola Data QC

Gambar 5 merupakan gambar activity diagram proses kelola data QC, pada diagram diatas tergambarkan seorang admin QC (staf QC) melakukan login ke sistem, apabila berhasil login, sistem akan menampilkan menu utama sistem, kemudian admin QC dapat memilih data hasil QC bagian/proses yang diinginkan untuk dilakukan aktifitas pemasukan data hasil QC. Setelah data hasil QC dberhasil dimasukan maka sistem akan menginformasikan bahwa data berhasil dimasukan, dan selanjutnya dapat ditampilkan dalam laporan.

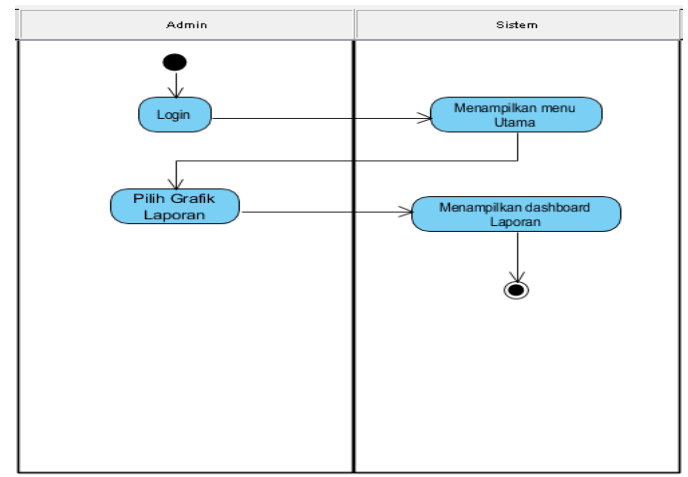

Gambar 6. Activity Diagram Kelola Laporan QC 
Gambar 6 merupakan gambar activity diagram proses kelola laporan data QC, pada diagram diatas tergambarkan seorang admin QC (staf QC) melakukan login ke sistem, apabila berhasil login ke sistem maka akan tampil menu utama, kemudian admin QC dapat memilih laporan yang ingin dihasilkan.

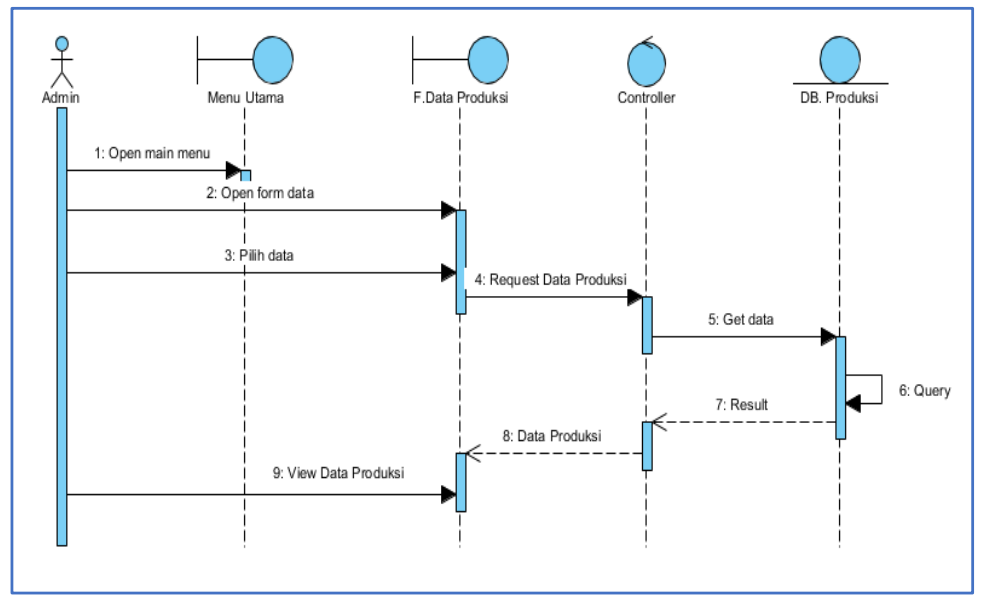

Gambar 7. Sequence Diagram Kelola Data Hasil Produksi

Gambar 7 merupakan gambar sequence diagram proses kelola data hasil produksi yang merupakan data masukan untuk proses laporan data QC, pada diagram diatas tergambarkan seorang pengguna (admin/staf QC), pertama kali akan masuk dalam sistem dan membuka menu utama, setelah itu sistem akan menampilkan submenu data hasil produksi, kemudian pengguna akan memilih menu data produksi sesuai dengan tanggal produksi. Proses selanjutnya controller akan menerima permintaan sesuai kriteria yang diinginkan pengguna, controller akan mengambil data dan melakukan query pada database sesuai kriteria data hasil produksi yang diinginkan pengguna. Setelah controller mendapatkan semua data yang yang dibutuhkan, maka data hasil produksi ditampilkan dalam tampilan aplikasi. Selanjutnya pengguna dapat memasukan data hasil QC dari proses produksi yang dihasilkan.

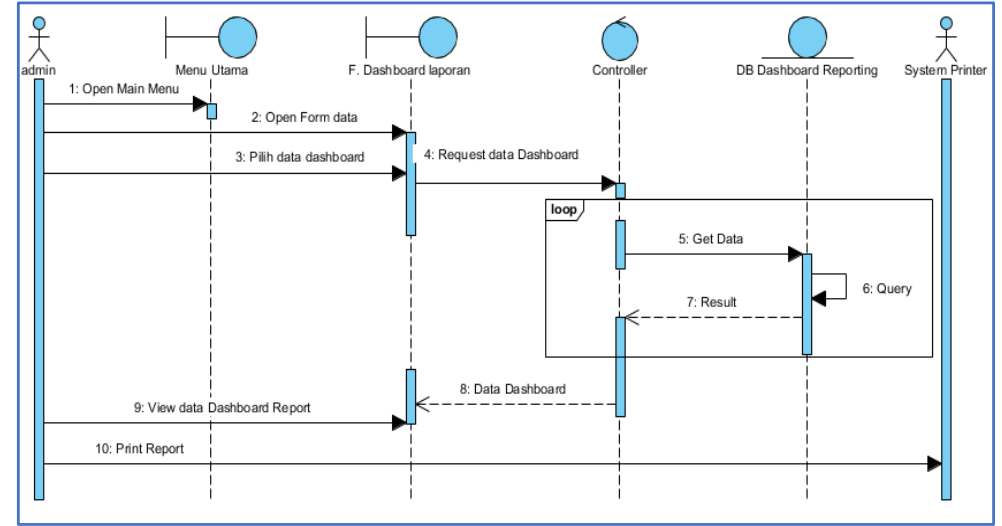

Gambar 8. Sequence Diagram Kelola Laporan QC

Gambar 8 merupakan gambar sequence diagram proses kelola laporan data QC, pada diagram diatas tergambarkan seorang pengguna (admin/staf QC), pertama kali akan masuk dalam sistem dan membuka menu utama, setelah itu sistem akan menampilkan sub-menu, kemudian pengguna akan memilih menu data dashboard untuk menampilkan dashboard dan laporan QC. Proses selanjutnya controller akan menerima permintaan sesuai kriteria yang diinginkan pengguna, controller akan mengambil data dan melakukan query pada database sesuai kriteria dashboard dan reporting yang diinginkan pengguna. Setelah controller mendapatkan semua data yang yang dibutuhkan, maka dashboard dan reporting dan reporting ditampilkan dalam tampilan aplikasi. Pengguna dapat melihat dashboard dan reporting yang dibutuhkan pada layar monitor atau dapat melakukan pencetakan dashboard dan reporting yang dihasilkan sistem. 


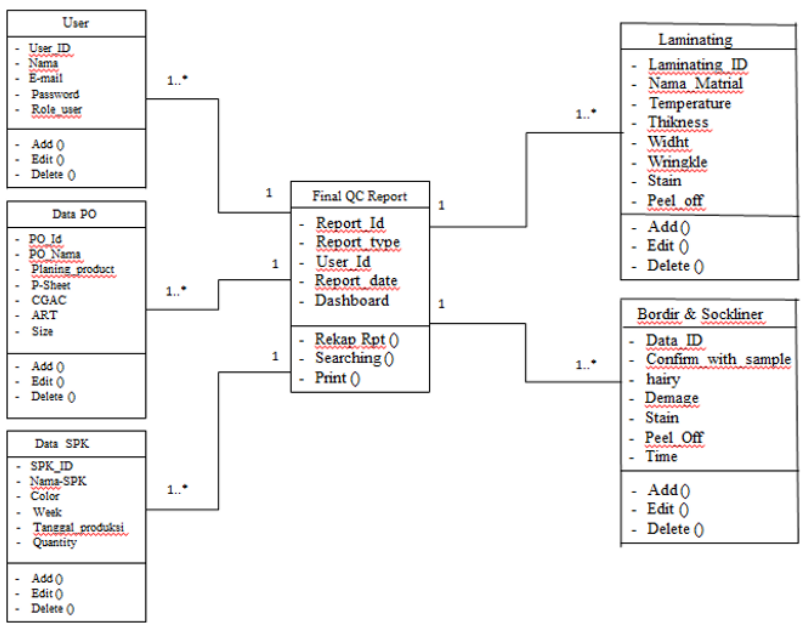

Gambar 9. Class Diagram

Gambar 9 merupakan gambar class diagram sistem informasi monitoring dan reporting quality control proses laminating berbasis web framework laravel, pada gambar class diagram diatas tergambarkan sistem yang dikembangkan memiliki 6 buah class yaitu class final QC report, class user, class data PO, class data SPK, class laminating dan class bordir \& sokliner. Keenam class tersebut memiliki atribut dan dapat diintegrasikan satu dengan lainnya dengan class final data report sebagai penghubung utama (hub).

\subsection{Tahapan pengembangan sistem}

Setelah seluruh perancangan sistem selesai dibuat, peneliti melakukan pengembangan sistem menggunakan bahasa pemrograman PHP dengan framework laravel. Peneliti menggunakan laravel karena laravel merupakan sebuah framework yang dapat membantu pengembang memaksimalkan penggunaan bahasa pemrograman PHP khususnya pengembangan aplikasi berbasis web.

Pengembangan sistem dilakukan selama tiga bulan mengacu pada perancangan sistem usulan sebagaimana telah dijabarkan sebelumnya. Pengembangan sistem menggunakan siklus Software Development Life Cycle (SDLC) model waterfall dimana merupakan metode pendekatan pengembangan sistem informasi yang sistematis sehingga membatu peneliti dapat mengembangan sistem dengan cepat sesuai kebutuhan pengguna.

\subsection{Tahapan uji coba Sistem}

Untuk memastikan kualitas sistem yang dihasilkan baik secara teknikal meliputi kestabilan dan keakuratan ata laporan yang dihasilkan sistem, maupun secara non teknikal untuk memastikan sistem yang dikembangkan sesuai dengan kebutuhan pengguna serta dapat menyelesaikan segala permasalahan pengolahan data yang dihadapi penguna, peneliti melakukan tahapan uji coba sistem.

Metode pengujian pada sistem yang dikembangkan menggunakan metode black box testing yaitu sebuah pengujian sistem yang didasarkan pada detail dari sistem yang dihasilkan dilihat dari tampilan aplikasi, fungsifungsi terdapat pada sistem serta kesesuaiannya dengan apa yang dibutuhkan pengguna.

\subsection{Tahapan Perbaikan Sistem}

Tahapan perbaikan sistem merupakan tahapan untuk memperbaiki semua modul dan fungsi-fungsi yang dianggap belum dapat memenuhi kebutuhan pengguna setelah dilakukan uji coba sistem. Dari hasil pengujian awal sistem yang dikembangkan, terdapat beberapa fitur yang kurang sesuai dengan kebutuhan pengguna, terutama berkaitan dengan tampilan laporan yang dihasilkan sistem, kemudian peneliti melakukan perbaikan sesuai permintaan pengguna.

Proses perbaikan sistem membutuhkan watu dua minggu dan setelah sistem diperbaiki, peneliti kembali melakukan klarifikasi hasil perbaikan kepada pengguna, setelah pengguna menyetujui perbaikan yang dilakukan langkah selanjutnya adalah tahapan implementasi sistem. 


\subsection{Tahapan 6 Implementasi Sistem}

Tahapan implementasi dimulai dari proses persiapan infrastuktur perangkat keras meliputi server, personal computer yang akan digunakan oleh pengguna dan pemasangan serta setting jaringan komputer $\mathrm{d}$ area kerja bagian QC PT Victory Chingluh Indonesia.

Langkah selanjutnya, peneliti melakukan instalasi dan setting aplikasi yang dikembangkan di sertver dan melakukan ujicoba pengoperasian sistem aplikasi di personal computer pengguna. Tahapan terakhir dari proses penelitian pengembangan sistem informasi monitoring dan reporting quality control proses laminating berbasis web framework laravel adalah melakukan pelatihan penggunaan aplikasi yang digunakan bagian QC PT Victory Chingluh Indonesia ke semua pengguna sistem.

\section{HASIL DAN PEMBAHASAN}

Hasil dari penelitian yang dilakukan adalah terbangunnya sebuah sistem informasi monitoring dan reporting quality control proses laminating berbasis web, sistem telah mengimplementasikan di bagian QC PT Victory Chingluh Indonesia dengan beberapa fitur sesuai dengan kebutuhan pengguna.

\subsection{Tampilan Antar Muka}

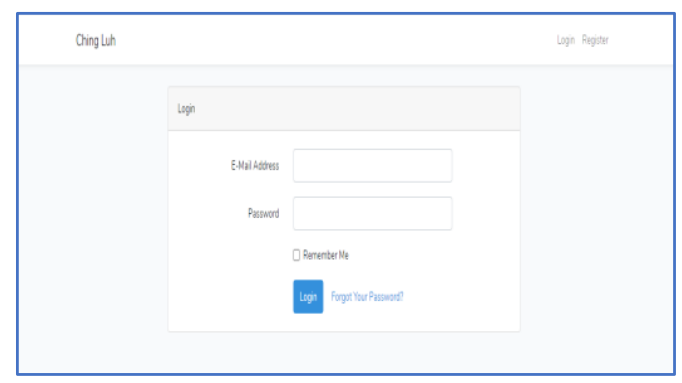

Gambar 10. Menu Login

Gambar 10 merupakan tampilan menu login sistem informasi monitoring dan reporting quality control proses laminating, pada menu login pengguna yang ingin masuk ke sistem harus memasukan email address dan password yang sudah didaftarkan sebelumnya oleh administrator sistem.

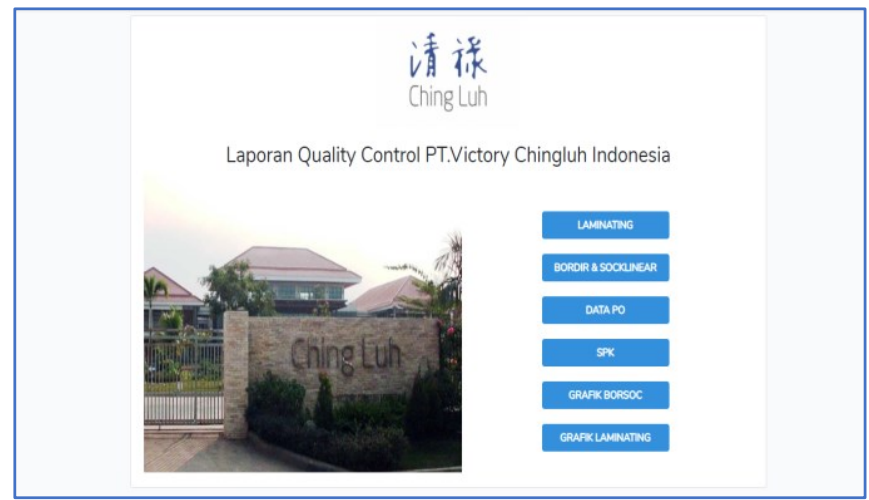

Gambar 11. Tampilan Menu Utama

Setelah pengguna berhasil masuk ke dalam sistem, maka sistem akan menampilkan tampilan menu utama sebagaimana gambar 11 diatas. Pada menu utama terdapat beberapa pilihan sub-menu yang terdapat pada sistem yang dikembangkan, sub-menu tersebut antara lain:

a. Laminating, merupakan sub-menu yang memungkinkan admin/staf QC melakukan input data QC hasil proses laminating.

b. Bordir \& soklinear, merupakan sub-menu yang memungkinkan admin/staf QC melakukan input data QC hasil proses bordir dan soklinear.

c. Data pro, merupakan sub-menu yang memungkinkan admin/stafQC melakukan input bahan baku dari proses produksi yang akan dilakukan.

d. SPK merupakan sub-menu yang memungkinkan admin/staf QC melakukan input data SPK (Surat Perintah Kerja) yang menjadi acuan bagian produksi melakukan proses produksi laminating dan border soklinier

e. Grafik borsoc merupakan sub-menu yang memungkinkan admin/staf QC menampilkan dan mencetak laporan bordir soklinier dalam bentuk grafik (daskboard). 
f. Grafik laminating, merupakan sub-menu yang memungkinkan admin/staf QC menampilkan dan mencetak laporan laminating dalam bentuk grafik (daskboard).

\subsection{Tampilan Grafik Monitoring dan Reporting proses QC}

Berikut ini tampilan grafik dan laporan sistem informasi monitoring dan reporting quality control proses laminating berbasis web framework laravel yang dikembangkan.

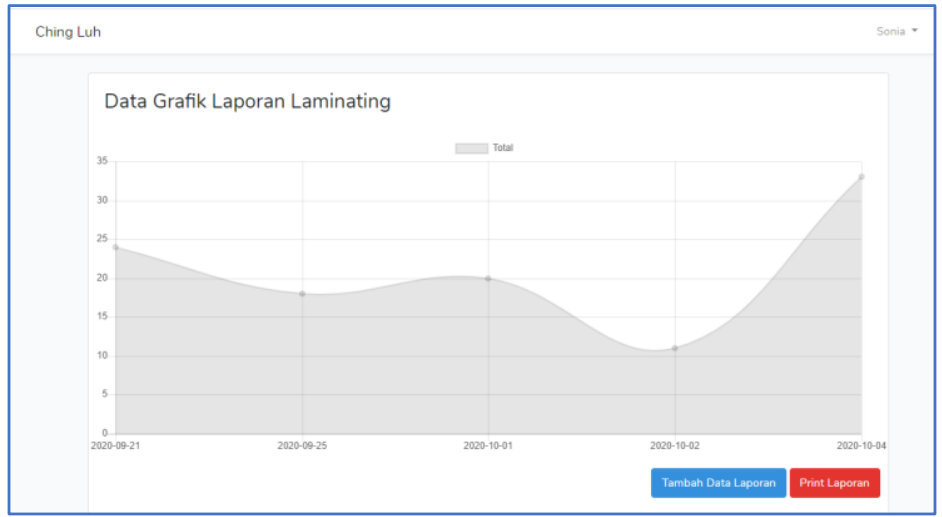

Gambar 12. Grafik Monitoring Proses QC

Gambar 12 merupakan tampilan dashboard (grafik) laporan proses QC laminating, tampilan ini dapat dilihat oleh admin/staf QC dan manajer QC. Dengen adanya dashboard (grafik) laporan proses QC laminating, manajer bagian QC dapat dengan cepat melihat peningkatan/penurunan status hasil proses QC laminating dalam kurun waktu tertentu, sehingga manajer dapat membuat analisa hasil proses QC yang berjalan dengan cepat dan akurat.

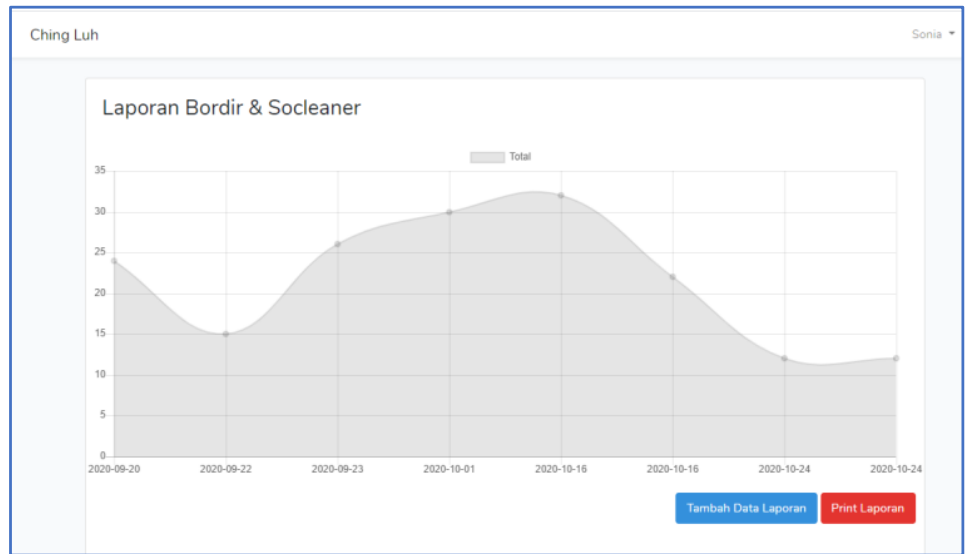

Gambar 13. Grafik Menu Dashboard Bordir \& Sockliner

Gambar 13 diatas merupakan tampilan Dashboard Bordir \& Sockliner, yang merupakan hasil laporan yang dihasilkan dalam satu minggu atau lebih. Grafik Menu Dashboard Bordir \& Sockliner dapat dilihat oleh pengguna sistem yang berposisi sebagai kepala bagian dan pengguna sistem yang berposisi sebagai admin yang melakukan proses pemasukan data hasil QC di PT Victory Chingluh Indonesia.

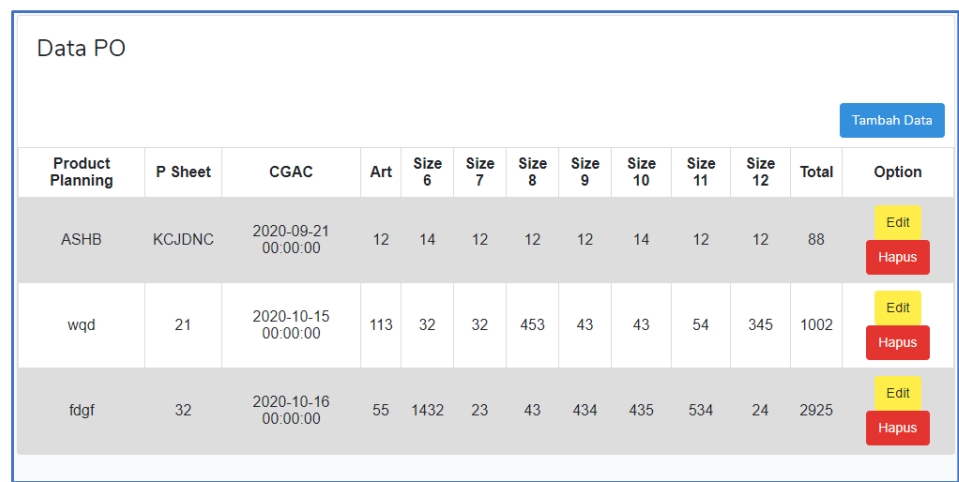

Gambar 14. Tampilan Lamporan Data PO 
Gambar 14 merupakan tampilan laporan data PO (Purchase Order) yang dibuat bagian produksi sebelum proses produksi dilakukan. Data PO ini akan dijadikan referensi awal oleh staf QC dalam melakukan proses QC hasil proses produksi.

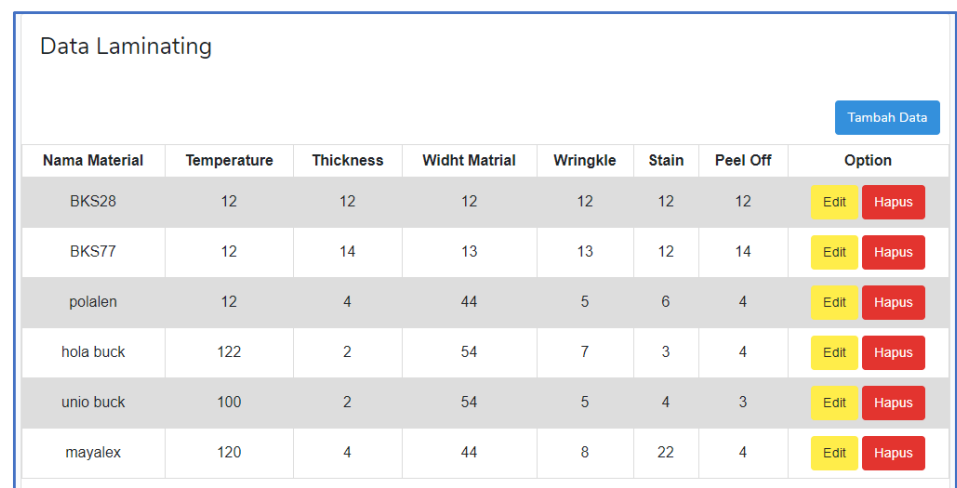

Gambar 15. Grafik Monitoring Proses QC

Gambar 15 merupakan tampilan laporan data QC proses laminating, laporan ini merupakan laporan hasil QC dalam periode tertentu yang ditetapkan pengguna sebelumnya. Dengen adanya laporan proses QC laminating, manajer bagian QC dapat melihat status hasil proses QC laminating dalam kurun waktu tertentu, data dalam laporan ini juga dapat dijadikan masukan untuk membuat analisa dari proses QC pada kurun waktu tertentu sesuai kebutuhan pengguna.

\subsection{Pengujian Sistem}

Sistem informasi monitoring dan reporting quality control proses laminating berbasis web framework laravel yang dikembangkan diuji menggunakan pengujian sistem metode black block testing sebagaimana tabel 1.

Tabel 1. Tabel Pengujian Black Box Testing

\begin{tabular}{|c|c|c|c|c|c|c|}
\hline \multicolumn{4}{|c|}{$\begin{array}{l}\text { Nama Aplikasi : } \\
\text { sistem informasi monitoring dan reporting quality control proses } \\
\text { laminating berbasis web framework laravel }\end{array}$} & \multicolumn{3}{|c|}{$\begin{array}{l}\text { Tanggal Pengujian: } \\
15 \text { Januari } 2021\end{array}$} \\
\hline & & & & \multicolumn{3}{|c|}{$\begin{array}{l}\text { Penguji: } \\
\text { Ibu Ariyani dan Sonia Maylinda }\end{array}$} \\
\hline \multirow{2}{*}{ No } & \multirow{2}{*}{$\begin{array}{c}\text { Halaman } \\
\text { Yang Diuji }\end{array}$} & \multirow{2}{*}{ Aksi Aktor } & \multicolumn{3}{|c|}{ Reaksi Sistem } & \multirow{2}{*}{ Hasil } \\
\hline & & & & Benar & Salah & \\
\hline A. & \multicolumn{6}{|c|}{ Halaman Pengujian Sistem Admin/Staf QC } \\
\hline 1. & $\begin{array}{l}\text { Halaman } \\
\text { Awal }\end{array}$ & $\begin{array}{l}\text { Pilih menu } \\
\text { Log in }\end{array}$ & $\begin{array}{l}\text { Masuk ha } \\
\text { admin }\end{array}$ & $\operatorname{man} \log$ in & $\begin{array}{l}\text { Tidak berhasil masuk } \\
\text { halaman } \log \text { in admin }\end{array}$ & $\begin{array}{c}\text { Sesuai } \\
\text { kebutuhan }\end{array}$ \\
\hline 2. & $\begin{array}{l}\text { Login Staf } \\
\text { QC }\end{array}$ & $\begin{array}{l}\text { input user name dan } \\
\text { password }\end{array}$ & Masuk ha & man utama & $\begin{array}{l}\text { Tidak berhasil masuk } \\
\text { halaman utama admin }\end{array}$ & $\begin{array}{c}\text { Sesuai } \\
\text { kebutuhan }\end{array}$ \\
\hline 3. & Log out & Pilih menu $\log$ out & $\begin{array}{l}\text { Melakuka } \\
\text { menampil } \\
\text { awal }\end{array}$ & $\begin{array}{l}\text { log out dan } \\
\text { an halaman }\end{array}$ & $\begin{array}{l}\text { Tidak berhasil } \\
\text { melakukan proses } \log \\
\text { out }\end{array}$ & $\begin{array}{c}\text { Sesuai } \\
\text { kebutuhan }\end{array}$ \\
\hline \multirow[t]{3}{*}{4.} & \multirow[t]{3}{*}{ Data Laporan } & $\begin{array}{l}\text { Melakukan penambahan data } \\
\text { Laporan dengan input } \\
\text { seluruh data Laporan yang di } \\
\text { hasilkan }\end{array}$ & \multicolumn{2}{|c|}{$\begin{array}{l}\text { Data Laporan } \\
\text { bertambah }\end{array}$} & $\begin{array}{l}\text { Menampilkan informasi } \\
\text { kesalahan jika ada data } \\
\text { yang tidak diisi }\end{array}$ & $\begin{array}{c}\text { Sesuai } \\
\text { kebutuhan }\end{array}$ \\
\hline & & $\begin{array}{l}\text { Melakukan perubahan data } \\
\text { laporan sesuai perubahan } \\
\text { yang diinginkan }\end{array}$ & \multicolumn{2}{|c|}{$\begin{array}{l}\text { Data laporan terbaru } \\
\text { berhasil disimpan }\end{array}$} & $\begin{array}{l}\text { Menampilkan informasi } \\
\text { kesalahan jika ada data } \\
\text { yang tidak diisi }\end{array}$ & $\begin{array}{c}\text { Sesuai } \\
\text { kebutuhan }\end{array}$ \\
\hline & & $\begin{array}{l}\text { Melakukan penghapusan } \\
\text { data laporan }\end{array}$ & \multicolumn{2}{|c|}{ Data Laporan terhapus } & $\begin{array}{l}\text { Data Laporan tidak } \\
\text { terhapus }\end{array}$ & $\begin{array}{c}\text { Sesuai } \\
\text { kebutuhan }\end{array}$ \\
\hline 5. & $\begin{array}{l}\text { Ubah } \\
\text { password }\end{array}$ & $\begin{array}{l}\text { Melakukan perubahan } \\
\text { password admin }\end{array}$ & \multicolumn{2}{|c|}{$\begin{array}{l}\text { Perubahan Password } \\
\text { berhasil }\end{array}$} & $\begin{array}{l}\text { tidak berhasil merubah } \\
\text { Password }\end{array}$ & $\begin{array}{c}\text { Sesuai } \\
\text { kebutuhan }\end{array}$ \\
\hline
\end{tabular}




\begin{tabular}{|c|l|l|l|l|c|}
\hline B. & \multicolumn{5}{|c|}{ Halaman Pengujian Sistem Kepala Bagian } \\
\hline 1. & $\begin{array}{l}\text { Log in Kepala } \\
\text { Bagian }\end{array}$ & $\begin{array}{l}\text { Memasukkan } \text { user name dan } \\
\text { password }\end{array}$ & $\begin{array}{l}\text { Masuk ke halaman } \\
\text { utama Laporan }\end{array}$ & $\begin{array}{l}\text { Tidak masuk ke } \\
\text { halaman utama Laporan }\end{array}$ & $\begin{array}{c}\text { Sesuai } \\
\text { kebutuhan }\end{array}$ \\
\hline 2. & Log out & Pilih menu log out & $\begin{array}{l}\text { Melakukan log out dan } \\
\text { menampilkan halaman } \\
\text { awal }\end{array}$ & $\begin{array}{l}\text { Tidak melakukan log } \\
\text { out } \\
\text { kebutuhan }\end{array}$ \\
\hline 3. & $\begin{array}{l}\text { Melihat Data } \\
\text { Laporan }\end{array}$ & $\begin{array}{l}\text { Membuka Laporan yang } \\
\text { diinginkan }\end{array}$ & Membuka hasil laporan & Menampilkan laporan & $\begin{array}{c}\text { Sesuai } \\
\text { kebutuhan }\end{array}$ \\
\hline 4. & Print laporan & $\begin{array}{l}\text { Memiih print laporan yang } \\
\text { dinginkan }\end{array}$ & Menmapilkan laporan & $\begin{array}{l}\text { Tidak menampilkan } \\
\text { kesalahan data }\end{array}$ & $\begin{array}{c}\text { Sesuai } \\
\text { kebutuhan }\end{array}$ \\
\hline 6. & $\begin{array}{l}\text { Pencarian } \\
\text { Laporan }\end{array}$ & $\begin{array}{l}\text { Melakukan pencaian laporan } \\
\text { Sesuai }\end{array}$ & $\begin{array}{l}\text { Menampilkan Data } \\
\text { yang telah dicari }\end{array}$ & $\begin{array}{l}\text { Tidak menampilkan } \\
\text { data yang telah dicari }\end{array}$ & $\begin{array}{c}\text { Sebutuhan } \\
\text { kebanan }\end{array}$ \\
\hline
\end{tabular}

\section{KESIMPULAN}

Penelitian ini telah menghasilkan sebuah sistem informasi monitoring dan reporting quality control proses laminating berbasis web framework laravel yang dapat membantu proses pencatatan dan pembuatan laporan QC di PT. Victory Chingluh Indonesia. Dengan adanya sistem ini admin/staf QC sangat terbantu dalam membuat/menyajikan laporan yang dibutuhkan pimpinan bagian QC. Sistem ini juga sangat membantu pimpinan bagian QC dalam proses analisa data hasil QC dalam rangka proses pengambilan keputusan karena sistem yang dikembangkan memiliki fitur dashboard yang membuat pimpinan dapat dengan cepat dan akurat melihat grafik pertumbuhan/penurunan hasil proses QC yang berjalan.

Sistem informasi monitoring dan reporting quality control proses laminating yang dihasilkan berbasis web sehingga tidak memerlukan setting khusus di komputer pengguna, cukup dengan menggunakan komputer yang terkoneksi ke jaringan dan server serta menggunakan browser maka pengguna dapat mengakses sistem yang dikembangkan. Penggunaan sistem informasi berbasis web ini sangat mudah digunakan dan dilekukan pemeliharaan sistem

Dari hasil penelitian yang dilakukan, berkaitan dengan proses pengembangan sistem informasi berbasis komputer, penggunaan framework laravel mempermudah peneliti mengembangkan sistem ini dengan cepat, dan memiliki tampilan yang bagus dari sisi pengguna.

\section{UCAPAN TERIMAKASIH}

Terima kasih peneliti sampaikan kepada Ibu Ariyani selaku Departement Head QC PT. Victory Chingluh Indonesia yang telah memberikan kesempatan, membantu peneliti dan meluangkan waktu serta memberikan sumbangsih saran selama peneliti melakukan proses penelitian di bagian QC dalam rangka mengembangkan sistem informasi monitoring dan reporting quality control proses laminating berbasis web framework laravel.

\section{REFERENCES}

[1] P. Kotler and G. Amstrong, Principles of Marketing, Ed. 14th. New Jersey: Pearson: Prentice Hall - New Jersey, 2012.

[2] A. Herdiansah, R. Rosdiana, and F. Wulandani, "Pengembangan Dashboard Kontrol Pengendalian Mutu Pada Bagian Printing Dan Emboss Pt. Megah Mas Prima," J. Ilm. Matrik, vol. 21, no. 3, pp. 266-278, 2019, doi: 10.33557/jurnalmatrik.v21i3.731.

[3] X. Shui, A. Shangguan, Y. Yu, and G. Hailin, “Advanced Quality Control at Raw Material Kickoff Stage,” in IEEE International Conference on Industrial Engineering and Engineering Management (IEEM), 2015, pp. 943-946.

[4] M. Rusdiana., Irfan, Sistem Informasi Manajemen, Edisi 1. Bandung: CV Pustaka Setia, 2014

[5] A. Herdiansah, "Sistem Pendukung Keputusan Referensi Pemilihan Tujuan Jurusan Teknik di Perguruan Tinggi Bagi Siswa Kelas XII IPA Menggunakan Metode AHP,” J. MATRIK, vol. 19, no. 2, pp. 223-234, 2020, doi: https://doi.org/10.30812/matrik.v19i2.579.

[6] Sudaryono, Metodologi Riset di Bidang IT: Panduan Praktis, Teori dan Contoh Kasus, Ed.1. Yogyakarta: Andi Offset, 2015. 
[7] N. Fitriawati, A. Herdiansah, and A. Gunawan, "Sistem Informasi Program Keluarga Harapan Studi Kasus Kecamatan Kosambi Tangerang,” J. Tek. Inform. Univ. Muhammadiyah Tangerang, vol. 3, no. 2, pp. 21-26, 2019.

[8] Soleh, M. A. Dewi, Arfiah, and Asdin, "Metode Peninjauan Dashboard Dari Business Intelligence Untuk Membuat Keputusan Lebih Baik,” Semin. Nas. Teknol. Inf. dan Multimed., pp. 13-18, 2013.

[9] R. Gitzel, S. Turring, and S. Maczey, "A Data Quality Dashboard for Reliability Data," in IEEE 17th Conference on Business Informatics, 2015, pp. 90-91.

[10] L. Rahmayani and Haryanto, "Rancang Bangun Aplikasi Monitoring Laporan Quality Control Dan Defective Produksi Sepatu Berbasis Web (Studi Pada Pt. Panarub Industry,” J. JUTIS Univ. Islam Syekh-Yusuf Tangerang, vol. 6, no. 2, pp. 76-81, 2018.

[11] B. Yuliandra and R. Wulan, "Perancangan Sistem Informasi Pengendalian Kualitas pada Laboratorium Proses IV PT X," J. Optimasi Sist. Ind., vol. 17, no. 2, pp. 113-125, 2018.

[12] Fatmariani and A. Saputro, "Pemodelan Sistem Informasi Quality Control System (QCS) Sektor Industri Pariwista Dinas Kebudayaan dan Pariwisata," Sink. J. Penelit. Tek. Inform. - Politek. Ganesha Medan, vol. 3, no. 1, pp. 1-8, 2018.

[13] R. Pressman, Software Engineering: A Practitioner's Approach, 7th editio. New York: The McGraw-Hill Company, 2015. 